\title{
Socially Embedded Academic Emotions in School
}

\author{
Henrika Anttila ${ }^{1}$, Kirsi Pyhältö ${ }^{1,2}$, Janne Pietarinen ${ }^{3} \&$ Tiina Soini ${ }^{3,4}$ \\ ${ }^{1}$ Faculty of Educational Sciences, University of Helsinki, Helsinki, Finland \\ ${ }^{2}$ Faculty of Educational Sciences, University of Oulu, Oulu, Finland \\ ${ }^{3}$ School of Applied Educational Science and Teacher Education, University of Eastern Finland, Joensuu, Finland \\ ${ }^{4}$ School of Education, Universtiy of Tampere, Tampere, Finland \\ Correspondence: Henrika Anttila, Faculty of Educational Sciences, University of Helsinki, Helsinki, Finland.
}

Received: January 22, 2018 Accepted: February 20, 2018 Online Published: March 8, 2018

doi:10.5539/jel.v7n3p87 URL: https://doi.org/10.5539/jel.v7n3p87

\begin{abstract}
School is a central arena for a wide amount of emotions. Previous research on academic emotions has, however, mainly focused on achievement, engagement and teaching, situated in classroom. The social embeddedness, as well as different learning environments of school, continue to be neglected in the research literature. Our study focuses on examining socially embedded academic emotions in school, including emotions described in peer interactions and in teacher-pupil interactions. Furthermore, the aim of the study was to investigate socially embedded academic emotions situated in both informal and formal learning environments. In the study, we combine both qualitative and quantitative methods by using picture tasks and questionnaires. In total, 146 sixth and eighth graders participated in the study. The results of our study showed that the interaction between teachers and peers is a central arena for pupils' described socially embedded academic emotions in school. Furthermore, our study emphasizes the role of an informal learning environment as an important setting for socially embedded academic emotions. Practical and theoretical implications of these findings are discussed.
\end{abstract}

Keywords: emotion, peer interaction, teacher-pupil interaction, formal learning environment, informal learning environment

\section{Introduction}

Children spend a significant amount of their adolescence in school attending classes, completing projects, taking exams and building social relationships both during and between lessons. Thus, school is a central arena for experiencing emotions that further effect pupils' daily lives both in- and outside of school. Previous studies have shown that emotions play an important role in learning, social relationships, and school attendance (e.g., Lewis, Huebner, Malone, \& Valois, 2011; Lyubomirsky, King, \& Diener 2005; Pekrun \& Linnenbrink, 2014). For instance, pupils' positive emotions have been shown to affect positively their academic performance, study engagement and motivation (e.g., Lewis et al., 2011; Linnenbrink-Garcia, Rogat, \& Koskey, 2011; Pekrun, Goetz, Titz, \& Perry, 2002). Moreover, the social interactions within the school community, particularly teacher-pupil and peer interactions provide an arena for various emotions, contributing not only to pupils' academic achievement (e.g., Beilock, Gunderson, Ramirez, \& Leine, 2010; Furrer \& Skinner, 2003; Ulmanen, Soini, Pietarinen, \& Pyhältö, 2016; Véronneau \& Vitaro, 2007; Wentzel \& Caldwell, 1997; Witkow \& Fuligni, 2010), but also to their overall school experience (e.g., Aritzetaa, Balluerkaa, Gorostiagaa, Alonso-Arbiola, Haranburua, \& Gartzia, 2015). Furthermore, positive emotions in peer interaction, are crucial for pupils' positive development and wellbeing (Bacete, Perrin, Schneider, \& Blanchard, 2014; Rubin, Bukowski, \& Laursen, 2009). Previous studies on socially embedded emotions in school have mainly focused on emotional transmission, school climate and peer bullying (e.g., Aritzetaa et al., 2015; Barhight, Hubbard, \& Hyde, 2013; Becker, Goetz, Morger, \& Ranelucci, 2014; Frenzel, Goetz, Lüdtke, Pekrun, \& Sutton, 2009).

Thus, understanding of the similarities and differences in the socially embedded emotions within the school environment, including teacher-pupil interaction, and in peer interaction is still developing. Furthermore, as far as we know, there are no previous studies about emotions experienced in less-formal school settings, such as between classes, in recess settings, and how the emotions embedded in such interactions are associated with pupils' school thriving or their cynicism at school. In order to gain a better understanding of pupils' emotions embedded in the two most central social relationships in school, teacher-pupil and peer interaction in both 
classroom and during recess are explored. The present study focuses on exploring the following questions: 1) What kind of socially embedded emotions do pupils report in formal and informal learning environments of school? 2) What kind of variation can be detected in reported emotions in teacher-pupil, and in peer interactions within the formal and informal school environment? 3) How are the reported emotions associated with grade point average (GPA), school grade, thriving in school and cynicism towards school?

\section{School as a Central Arena for Emotions}

\subsection{Socially Embedded Academic Emotions}

Academic emotions refer to a set of emotions that are experienced in pedagogical settings, while engaging in pedagogical activities, such as teaching, studying and learning. They are active and short-lived states that rise in response to external stimuli, entailing both a bodily reaction and an evaluative response (Baumeister \& Bushman, 2007; Do \& Schallert, 2004). Low-intensity emotions, often referred to as moods (Pekrun, 2006), have been suggested to be less-specific, longer lasting reference objects (i.e., Schutz, Hong, Cross, \& Osbon, 2006). The basic function of emotions is to prepare us to act and enable us to avoid harm and orientate towards safety, i.e., to keep us alive. The basic characteristic of an emotion is the valence that refers to the degree of pleasantness of the emotion, distinguishing positive emotions (such as enjoyment and relief) from negative ones (such as anxiety and boredom). Negative emotions help us to avoid danger, whereas positive emotions guide our actions and behavior towards pleasantness and wellbeing. In this study, focus is on exploring pupils' socially embedded academic emotions in school in terms of the valence, since it directs our behavior and thus may have a great impact regarding pupils' actions.

Emotions are context dependent (e.g., Ainley \& Hidi 2002; Järvenoja \& Järvelä, 2009; Schutz \& Pekrun, 2007; Volet \& Järvelä, 2001) and most often triggered by social events (e.g., Averill, 1982; Kemper, 1978; Oatley \& Johnson-Laird, 1987). Previous studies suggest that social processes shape and are shaped by emotions (e.g., Leary, 2000; Oatley, 2000; Parkinson, Fischer, \& Manstead, 2005). Moreover, emotions make it possible to put oneself into another's shoes (Ioannidou \& Konstantikak, 2008) promoting pro-social interaction between, for example, teacher and pupils. School provides a complex social environment, where pupils experience a variety of academic emotions and have the opportunity to practice their emotional skills (e.g., Baudoin \& Galand, 2017; Denham, Bassett, \& Zinsser, 2012). Relationships with teachers and peers are a particularly important part of this environment.

Emotions are frequently communicated to other people and are a central part of everyday relationships (e.g., Fridlund, 1991; Rimé, Finkenauer, Luminet, Zech, \& Philippot, 1998; Rimé, Mesquita, Philippot, \& Boca, 1991). Through communicating emotions, we provide information about our emotional state, our perceptions of the world and the nature of relationships with others (Hess \& Kirouac, 2004).

Moreover, emotions are contagious through non-verbal clues, such as facial and gestural expressions as well as the pitch, loudness and timbre of a voice (Pekrun, Muis, Frenzel, \& Goetz, 2017). These signals give clues to others of the experienced emotions and may be mimicked to the point of emotional transmission and contagion (Nakahashi \& Ohtsuki, 2015; Singer \& Lamm, 2009). Communication and transmission of emotions can, at best, smoothen social interactions and create emotional closeness, i.e., they help synchronize and coordinate the interaction (Barsade, 2002; Hartfield, Cacioppo, \& Rapson, 1994). For instance, pupils' awareness of each other's emotions is likely to promote high-quality functional interaction. This may further enhance learning, motivation, and the experienced closeness in both teacher-pupil and peer interactions. However, only a few studies have investigated emotional contagion in educational settings (Becker et al., 2014). Frenzel, Goetz, Lüdtke, Pekrun, \& Sutton (2009) found that teachers' own experienced enjoyment contributed to pupils' experienced enjoyment in class to the extent that teacher enjoyment translates into enthusiasm during teaching. This implies that emotional contagion can occur similarly also in peer interaction, having potential to strengthen the social bonds between pupils. However, it is important to note that even though social interactions within a school community trigger emotions, they are always subjective, and each pupil has their unique emotional experience.

Previous studies have shown that pupils' wellbeing is highly socially embedded and emotionally intertwined (Pietarinen, Pyhältö, \& Soini, 2014; Pyhältö, Soini, \& Pietarinen, 2010). If socially embedded negative emotions, such as exhaustion and inadequacy, are frequently experienced and piled up, it may reduce thriving in school, predispose to burnout and cause cynicism towards schoolwork (e.g., Pietarinen et al., 2014; Salmela-Aro, Kiuru, Leskinen, \& Nurmi, 2009). In this regard, academic emotions experienced in peer and teacher-pupil interactions may have different impacts. 


\subsection{Emotions in Teacher-Pupil Interaction}

Teacher-pupil interaction provides a central arena for experiencing socially embedded academic emotions at school. Such interactions have been shown to raise emotions both in pupils and teachers (e.g., Frenzel et al., 2009; Gläser-Zikuda \& Fuß, 2008; Hargreaves, 2000; Maria, Dos Santos, \& Mortimer, 2003; Sutton \& Wheatley, 2003). Teachers' emotions have an impact on pupils' emotions, and vice versa. There is, for instance, evidence that teachers' positive emotions are likely to prompt also pupils' positive emotions, and further to be connected to pupils' achievement, study engagement and motivation (Becker et al., 2014; Beilock et al., 2010; Cubukcu, 2012; Demetriou, Wilson, \& Winterbottom, 2009; Frenzel et al., 2009). In addition, pupils' experienced joy of learning has been shown to have a positive association also with teachers' enjoyment (Becker et al., 2014; Hagenauer \& Volet, 2014). Moreover, positive emotions in teacher-pupil interaction are found to be related to both pupils' and teachers' wellbeing in school (e.g., Pekrun et al., 2017). For example, positive emotions in teacher-pupil interaction are seen as a buffer of teachers' stress in everyday life (Grams \& Jurowetzki, 2015), whereas negative emotions have a prevailing impact on their occupational wellbeing (Chang, 2013). Similarly, positive teacher-pupil interaction is shown to provide continuity and support for pupils suffering from negative school-related emotions (Madil, Gest, \& Rodkin, 2014). Accordingly, positive teacher-pupil interaction may also compensate for pupils' negative emotional experiences with peers.

There is evidence that especially pupils' classroom behavior has an impact on teachers' emotions (Frenzel, Götz, Pekrun, \& Jacob, 2009). Pupils' misbehavior in class has been shown to cause negative emotions in teachers (Chang, 2013). Furthermore, high-achieving and highly motivated pupils, closeness with pupils and witnessing pupils' advancement in learning are common sources of teachers' positive emotional experiences (e.g., Frenzel et al., 2009; Hagenauer, Hascher, \& Volet, 2015; Hargreaves, 2000). Previous literature has also shown that pupils' enjoyment, anger and anxiety are related to teachers' instructional behavior (Becker et al., 2014, Gläser-Zikuda \& Fuß, 2008; Sarason, 1984). For example, lack of feedback from teachers, unstructured learning material, unclear instructions and excessive external teacher control have been shown to cause negative emotions such as anxiety and anger (Anttila, Pyhältö, Soini, \& Pietarinen, 2016; Becker et al., 2014; Rantala \& Määttä, 2012; Sarason, 1984). Moreover, there is some tentative evidence that teachers who experience high job satisfaction are less stressed and exhausted and are perceived by pupils as giving better-quality instruction (Klussmann, Kunter, Trautwein, Lüdtke, \& Baumert, 2008; Kunter, Klusmann, Baumert, Richter, Voss, \& Hachfeld, 2013). Thus, it seems that the social interaction between teacher and pupils has an extensive impact on both teachers' and pupils' emotions.

There are some indications that emotions in teacher-pupil interactions might differ in primary and secondary schools. For instance, Hagenauer et al. (2015) found that class teachers experience more positive emotions compared to subject teachers. This may be due to the fact that class teachers spend more time with their pupils and thus have more opportunities to create positive teacher-pupil relationships (Hagenauer et al., 2015). Furthermore, the relationships between teacher and pupils seem to decline after the age-graded school transition, whereas peer relationships seems to become emotionally better and more significant (Symonds \& Galton, 2014; Pietarinen et al., 2014).

\subsection{Emotions in Peer Interaction}

Social emotions embedded in peer interactions are significant determinants of pupils' school experiences. Positive emotions in peer interaction, feelings of acceptance and sense of belonging are shown to be crucial for pupils' positive development and physical and mental wellbeing (Bacete et al., 2014; Rubin et al., 2009). They, for example, help pupils to develop social skills and cope with life challenges as well as, reduce stress and anxiety (Hoferichter, Raufelder, \& Eid, 2015; Rubin et al., 2009; Steinberg \& Morris, 2001). Positive social emotions are shown to be generated in close friendships and peer networks. However, school is also a place where pupils may experience anxiety and loneliness resulting from peer interactions (e.g., Graham \& Juvonen, 1998; Juvonen, Nishina, \& Graham, 2000; Veenstra, Lindenberg, Huitsing, Sainio, \& Salmivalli, 2014). Such experiences, if frequent and dominant, may result in negative emotions towards both schoolwork and peers in general, and further cause social anxiety and even depression among pupils (Pekrun et al., 2017; Graham \& Juvonen, 1998; Juvonen et al., 2000).

Moreover, pupils' emotions toward their peers are shown to contribute to their academic engagement and achievement (Furrer \& Skinner, 2003; Linnenbrink et al., 2011; Ulmanen et al., 2016; Véronneau \& Vitaro, 2007; Wentzel \& Caldwell, 1997; Witkow \& Fuligni, 2010). Positive emotions may, for example, promote enjoyment of learning that further increases effort and odds for academic success (e.g., Pekrun et al., 2002; Pekrun, Goetz, Perry, Kramer, \& Hochstadt, 2004). However, recent studies have also shown that positive emotions between 
peers do not necessarily increase pupils' commitment to schoolwork, but may also cause negative emotional experiences and cynicism towards school (Ulmanen et al., 2016). Furthermore, increased anxiety caused by competition for good grades may also result from positive peer interactions, where good academic performance is socially expected and valued (Pekrun et al., 2017).

Prior research on emotion in school has mainly focused heavily on the classroom. However, pupils spend a great amount of time outside the formal learning environment, in recess settings. During recess, pupils and teachers, but particularly peers interact with each other. Recess provides a more informal arena for interaction within school, typically defined as "non-curriculum time allocated by schools between lessons for children to engage in leisure activities" (Ridgers, Stratton, \& Fairclough, 2006). The recess settings may play a highly significant role in pupils' everyday school life, socially embedded emotions included. For example, it has been shown that negative emotional experiences between peers are commonly experienced during recess, out of teachers' sight (Veenstra et al., 2014). Previous studies have also shown that particularly lower-intensity emotions can last for longer periods of time and may transfer from one context to another (Anttila, Pyhältö, Soini, \& Pietarinen, 2017; Tennant, 1997). Accordingly, emotions aroused in recess settings might have an effect on learning in the classroom resulting in a situation where pupils might be unable to focus on studying for a long time (Tennant, 1997) or, at best, to be particularly wired to learn. Becker et al. (2014) found that pupils' moods before entering the classroom were related to both teachers' and pupils' emotions and instructional behavior. This implies that emotions experienced outside formal learning environments, for example during recess, might have a significant impact on pupils' learning in the next lesson. However, as far as we know there are no previous studies on pupils' emotions in recess settings.

\section{The Aim of the Study}

The present study aims to enhance understanding of pupils' socially embedded emotions in formal and informal school environments. The socially embedded emotions were explored both in teacher-pupil and in peer interaction. Moreover, the interrelation between the reported emotions and academic performance, thriving in school and cynicism were analyzed. The following research questions are addressed:

- What kind of socially embedded emotions do pupils report in formal and informal learning environments of school?

- What kind of variation can be detected in reported emotions in teacher-pupil, and in peer interactions within the formal and informal school environment?

- How are the reported emotions and GPA, school grade, thriving in school and cynicism towards school associated?

This study is part of a larger national research project: "Learning, pedagogical wellbeing and agency in comprehensive school" (see Soini, Pyhältö, \& Pietarinen, 2010 for more details).

\section{Methods}

\subsection{Finnish Comprehensive School System}

In Finland children typically start their school career with pre-primary school at the age of six. At the age of seven they start compulsory education, which includes primary (grades 1-6) and secondary (7-9) school. Nearly all children complete the nine-year compulsory basic education. The primary grades are usually taught by class teachers, who have their own class or group and teach the majority of subjects in the curriculum. In the secondary grades pupils are taught by specialized subject teachers. In Finland, all teachers must have a master's-level university degree (Niemi, 2012). There are no national testing systems or ability tracking for pupils (Kumpulainen \& Lankinen, 2012). Instead, the teachers are responsible for the assessment of the pupils on the basis of the objectives of the national curriculum. Schools do not select their pupils and pupils typically attend a nearby school. However, parents can, with some restrictions, choose the school of their preference. In the Finnish school system, the length of recesses or lunch break is not regulated by law. Teaching periods are divided into appropriate lengths and pupils enjoy several recesses daily (Haapala, Hirvensalo, Laine, Laakso, Hakonen, Lintunen, \& Tammelin, 2014), having approximately $80 \mathrm{~min}$ of recess per school day. Education is publicly funded (Finnish National Agency for Education, 2017), which includes textbooks, daily school dinners and health services such as dental care.

\subsection{Participants}

The data was collected from 6th and 8th graders from three comprehensive case schools around Finland, including one primary school (grades 1-6) and two primary and secondary schools (grades 1-9). The schools 
selected for this study represented typical Finnish suburban schools with pupil population ranging from 345 to 650 pupils. Altogether 146 6th and 8th graders participated to the study (73 6th graders, 73 8th graders), including 80 girls $(54.8 \%$ ), and 66 boys $(42.5 \%)$. The reason for selecting the 6th (age 12-13) and 8th (age: 15-16) graders was that the latter ones had recently undergone, and the former ones were approaching the primary-lower secondary school transition. In the lower secondary school (grades 7-9th) subject teachers teach a greater number of subjects compared to primary school (grades 1-6th) where class teachers teach a majority of the subjects. In the upper grades, the complexity of schools' social and pedagogical environments and the pupils' freedom of choice regarding study subjects increase (Sahlberg, 2011). Researchers received consent for study participation from the chief officers of the school district, the case schools, and the pupils and their parents. Participation in the study was voluntary and no extra credits were given to the pupils for participation.

\subsection{Picture Task Instrument}

A mixed methods approach was used in this study (e.g., Creswell \& Plano Clark, 2007; Johnson, Onwuegbuzie, $\&$ Turner, 2007) by combining both qualitative and quantitative methods in the data collection and analysis.

The qualitative data were collected by using picture tasks during a normal school day in the spring of 2011. The pupils were asked to write stories based on four pictures situated in formal and informal learning environments of the school (see Figure 1). The picture task technique was applied to access presumably hidden content and emotions using visual stimuli and imagery (Porr, Mayan, Graffigna, Wall, \& Vieira, 2011). Moreover, the pictures and questions may help to capture pupils' unfiltered perceptions and their school-related emotions (Branthwaite, 2002; Ulmanen, 2016). The pictures were created, based on a set of photographs, to represent normal school day situations that all pupils face during a normal school day. Furthermore, before data collection the instrument was ecologically validated by pupils, i.e. they recognized the situation represented in the photographs as typical school events. Accordingly, pupils had the opportunity to use their own past experiences and their current motivation to interpret the pictures (Porr et al., 2011). Hence, the instrument provided an opportunity to examine interactions both during school hours and between classrooms.

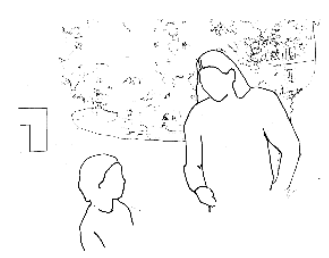

A teacher and a pupil on a break

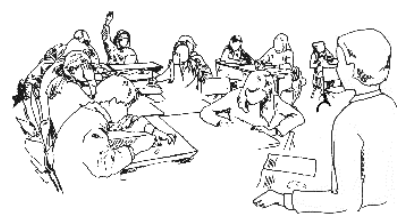

A teacher and pupils in a lesson



Pupils on a break

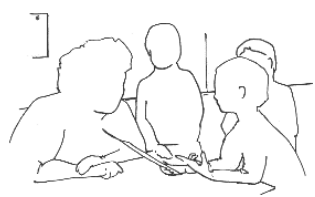

A teacher and pupils in a lesson

Figure 1. Picture task-instrument

The first two pictures were situated in recess settings and the two latter ones in the formal class-environment. Each of them were complemented with the following five questions: 1) What is happening at the moment?; 2) What has led to the event shown?; 3) What is the pupil/pupils thinking?; 4) What is the teacher thinking?; 5) What will happen next?

The quantitative survey data was collected from the same pupils in spring 2011. In this study, scales measuring cynicism and perceived satisfaction in school were utilized. The cynicism scale consisted of five items that indicated pupils' school-related cynicism. The positive wellbeing indicator, perceived school satisfaction, was measured with one thriving in school item, which pupils rated on a 10-point scale. The pupils rated all other items on a 5-point Likert scale (1 strongly disagree; 5 strongly agree). 
Table 1. The items and scales included in the questionnaire

\begin{tabular}{ll}
\hline Scales & Items \\
\hline Cynicism & "Going to school doesn't interest me at all" \\
& "I often feel like playing hooky from school" \\
& "Going to school feels unnecessary" \\
& "Often I feel I really don't want to come to school" \\
& "We have to study some quite useless stuff" \\
Thriving in school & $\begin{array}{l}\text { Please give us your own estimate, on a scale of 1 to 10: How much do you enjoy going to school? } \\
\text { (1= not all, 10= very much)? }\end{array}$ \\
\hline
\end{tabular}

Moreover, the pupils' school achievement was measured with their school grade point average, on the scale of 4 to 10 (4 indicating failure and 10 being excellent). The data was gathered from the school records from the 2011 spring term. Furthermore, background information was elicited about the pupils' age, gender and school grade. Before the data collection, the scales of the survey were validated. In addition, two pilot studies were carried out.

\subsection{Analysis}

At first, the qualitative picture task data were content analyzed (e.g., Chamberlain, 2006; Elo \& Kyngäs, 2007). To develop a functional coding procedure for the analysis, the text segments of pupils' descriptions of each picture were read carefully several times to obtain an overall understanding and to become familiar with the data.

In the first phase of the analysis, the direction of the interaction was analyzed (See Figure 2). This resulted in two categories: teacher-pupil interaction (entailing interplay between teacher and a pupil or a group of pupils) and peer interaction (entailing descriptions of pupils interacting with each other). Secondly, the emotional tone of the interaction was analyzed. This resulted in two categories: positive emotions (entailing expressions of positive emotions such as enthusiasm, joy, belonging and hope) and negative emotions (entailing expressions of negative emotions such as loneliness, anger, sadness and fear).

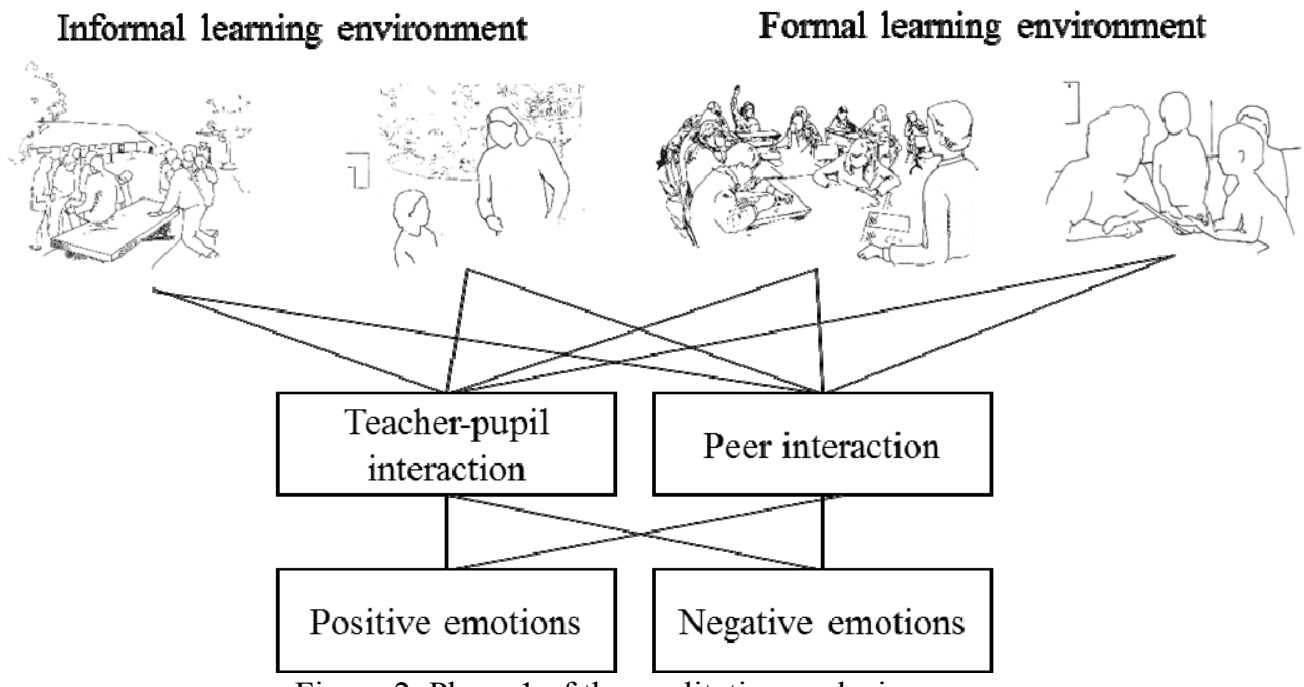

Figure 2. Phase 1 of the qualitative analysis

Based on the qualitative analysis, an overall emotional tone for teacher-pupil interaction and peer interaction was calculated for each pupil (Figure 3). This resulted in two categories for both teacher-pupil interaction and peer interaction: positive emotion index and negative emotion index. Pupils who explicated mostly positive emotions in teacher-pupil interaction were categorized in the positive emotion index regarding teacher-pupil interaction and pupils describing more negative emotions in teacher-pupil interaction were categorized in the negative emotion index. Emotion indexes in peer interaction were formed in the same way. 


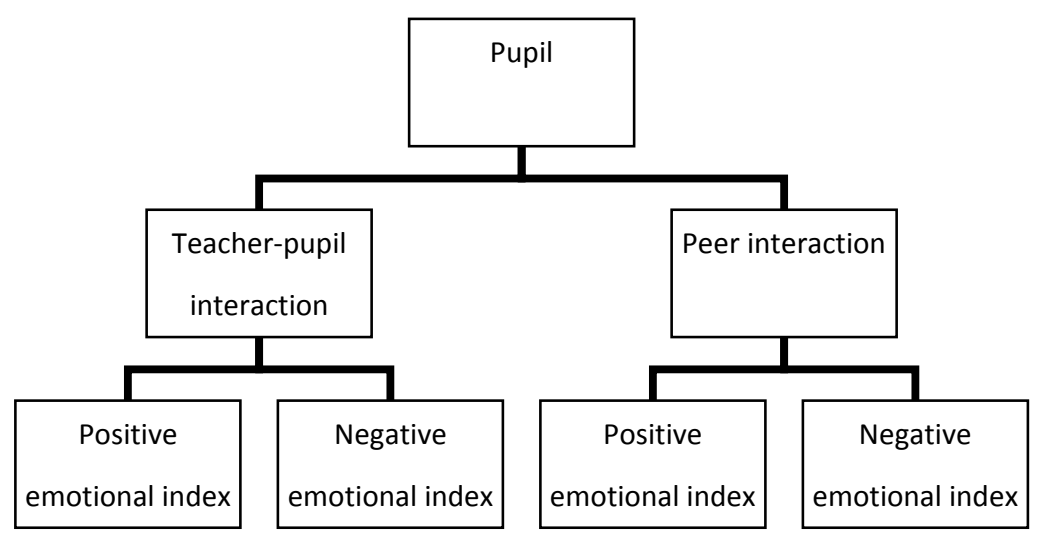

Figure 3. Phase 2 of the qualitative analysis

The categories resulting from the qualitative content analysis at the end of each analytical phase were validated by the research group (Miles \& Huberman, 1994). In the few cases on which there was disagreement, a consensus on the final categorization was reached in discussion among the researchers. In addition, 20 percent of the data was subjected to an independent parallel analysis. The independent parallel analysis was based on classification criteria. The inter-rater agreement was 91.4 percent.

Descriptive statistics of overall emotional tones, GPA, school grade, cynicism and thriving in school were calculated. Independent samples T-test was carried out to measure the association between overall emotional tones, cynicism, GPA and thriving in school (significance level $p<.05$ ). In addition, a $\chi 2$-test was carried out to measure the difference between sixth and eighth graders' overall emotional tones (significance level $\mathrm{p}<.05$ ).

\section{Results}

Our results showed that pupils described a wide variety of emotions in different school settings with peers and teacher-pupil interaction. Slightly more emotions embedded in social interaction with teachers $(53.2 \%)$ than in peer interactions (46.8\%) were described (See Table 2). Moreover, most of the reported emotions were situated in an informal learning environment $(\mathrm{f}=343)$, although a fair amount of emotions was also described in formal classroom situations ( $\mathrm{f}=253$ ).

Most of the socially embedded emotions in teacher-pupil interactions were situated in formal classroom learning environments often related to studying and teaching-learning activities such as pupils doing exercises or taking exams and the teacher teaching in front of the class or asking questions. The emotions that pupils described were mostly positive ( $\mathrm{f}=99$ ). They often explicated positive emotions such as gratitude, satisfaction and happiness in classroom situations where teacher was offering help. Pupils also acknowledged situations where a teacher expressed satisfaction towards pupils' learning-oriented behavior and competence. These descriptions entailed positive emotions of teachers and pupils', such as joy, happiness, satisfaction and pride.

1) Teacher is helping pupils; 2) When the pupils did not know; 3) Fortunately, the teacher helps; 4) I'm so happy to be helpfull; 5) They find out what the pupils did not know (Sixth grader, picture 4).

Socially embedded negative emotions in teacher-pupil interaction, both in formal $(\mathrm{f}=86)$ and informal $(\mathrm{f}=85)$ learning environments, were commonly related to situations where a teacher was disciplining pupils due to their misbehavior either during class or recess. Negative emotions, such as anger and frustration, were also described in situations where pupils did not agree with the teacher's view. Negative emotions in teacher-pupil interaction were also frequently related to pupils being ignored or not receiving help from the teacher. In these occasions pupils explicated emotions such as frustration, anxiety and confusion. Pupils also described situations where a teacher takes notice of a pupil standing alone in the courtyard and impresses worry over both a pupil's loneliness and school success. These emotional descriptions of worry were commonly situated in recess settings.

1) The teacher talks to the pupil about a dispute that took place during recess; 2) First there was a verbal argument and then the fists came out; 3) He is irritated and annoyed about the teacher's lecture; 4) The teacher is annoyed that the incident happened but he/she must correct the situation; 5) The pupil/ pupils get detention (Eighth grader, picture 2).

Most of the emotions reported in peer interaction were situated outside the class room, during recess. The emotions situated in recess settings between peers were typically negative, such as loneliness, sadness and 
anxiety ( $\mathrm{f}=139$ ), often resulted from being left alone or being bullied. Furthermore, pupils described anger and schadenfreude regarding situations where some pupils were tormenting others in school. Positive emotions described in recess settings were frequently related to having fun with friends and experiences of a strong sense of belonging among peers. In these situations pupils characterized positive emotions toward their peers, such as enjoyment, belonging and happiness.

1) There are two groups, some of the pupils are left outside; 2) Not for any particular reason, outsiders simply don't "fall" into groups; 3) Members of the group don't care. Some of them may think about the outsiders but do nothing because none of the others is stepping in either. The outsiders feel lonely; 4) Nothing (Eighth grader, picture 1).

1) Pupils are chatting; 2) The recess started; 3) It is nice to talk between classes; 4) Recess ends (Sixth grader, picture 1).

Socially embedded emotions in peer interaction were seldom reported in the formal learning settings. Negative emotions in the formal learning environment in peer interactions $(\mathrm{f}=36)$ were related to either other pupils' misbehavior in class or their interest in succeeding in schoolwork. These situations were reported to cause emotions such as frustration and anger. Moreover, positive emotions in class $(\mathrm{f}=32)$ with peers were related to having fun when working together towards a common goal. Also, positive emotions were described in situations where pupils expressed happiness for the success of their peers.

1) The pupils listen to the pupil standing in front of the class. They are writing at the same time; 2) The teacher ordered the pupil in front of the class; 3) Pupils respect the pupil standing in front of the class; 4) Good that the pupils are listening to each other; 5) Next, the pupil will take a seat and the others will applaud and admire the performance (Eighth grader, picture 3)

Table 2. Emotions in social interactions and in different learning environments

\begin{tabular}{llllll}
\hline Learning environment & \multicolumn{2}{l}{ Teacher-pupil interaction } & Peer interaction & & \\
\hline \multirow{2}{*}{ Formal } & Positive & Negative & Positive & Negative & Total \\
& $f=99$ & $f=86$ & $f=32$ & $f=36$ & $f=253$ \\
\multirow{2}{*}{ Informal } & $39.1 \%$ & $34 \%$ & $12.7 \%$ & $14.2 \%$ & $100 \%$ \\
& $f=47$ & $f=85$ & $f=72$ & $f=139$ & $f=343$ \\
\multirow{2}{*}{ Total } & $13.7 \%$ & $24.8 \%$ & $21 \%$ & $40,5 . \%$ & $100 \%$ \\
& $f=146$ & $f=171$ & $f=104$ & $f=175$ & $f=596$ \\
& $24.5 \%$ & $28.7 \%$ & $17.4 \%$ & $29.4 \%$ & $100 \%$ \\
\hline
\end{tabular}

Note. $f=$ frequency, $\%=$ percent

\subsection{Interrelation Between Socially Embedded Emotions, GPA, Cynicism, Thriving in School and School Grade}

The results showed that pupils' overall emotional descriptions were most commonly negative both in peer ( $\mathrm{f}=78)$ and in teacher-pupil interaction $(\mathrm{f}=78)$. Positive overall emotional tone in peer interaction $(\mathrm{f}=60)$ and in teacher-pupil interaction ( $\mathrm{f}=57$ ) were, however, also frequently detected (See Table 3 ). The descriptive analyses for items measuring cynicism, thriving in school and GPA with number of items, minimum/maximum/mean values, standard deviations and internal consistency are presented in Table 3. The results showed that pupils experienced somewhat low levels of cynicism and high levels of school thriving. Furthermore, the table shows that the internal consistency (Cronbach's Alpha) was good for the cynicism-scale.

Table 3. Descriptive statistics: frequency $(f)$, number of items $(\mathrm{N})$, minimum values (Min), maximum values (Max), mean values (Mean), standard deviations (SD) and internal consistency (Alpha)

\begin{tabular}{lllllll}
\hline & \multicolumn{2}{l}{ Teacher-pupil interaction } & \multicolumn{2}{l}{ Peer interaction } \\
\hline Positive emotion index & $f=57$ & & & $f=60$ & & \\
Negative emotion index & $f=78$ & & & $f=78$ & & \\
\hline & $\mathrm{N}$ & Min & Max & Mean & SD & Alpha \\
\hline Cynicism & 5 & 1 & 5 & 2.28 & .862 & .83 \\
Thriving in school & 1 & 1 & 10 & 7.70 & 1.66 & - \\
GPA & 1 & 5.59 & 9.64 & 7.90 & .878 & - \\
\hline
\end{tabular}


Further, the investigation showed that emotionally negatively loaded perception of teacher-pupil interactions were related to increased cynicism towards schoolwork $(\mathrm{t}=2.26 ; \mathrm{df}=136 ; \mathrm{p}=.025)$ and reduced school thriving $(\mathrm{t}$ $=-2.20 ; \mathrm{df}=129 ; \mathrm{p}=.03)$. However, no statistically significant interrelation between the overall emotional tones of peer interaction and thriving in school $(\mathrm{t}=.72 ; \mathrm{df}=131 ; \mathrm{p}=.47)$ or cynicism $(\mathrm{t}=-1.95 ; \mathrm{df}=134 ; \mathrm{p}=.05)$ were detected. There were no statistically significant differences in GPA between the overall emotional tone related to peer relationships $(\mathrm{t}=.37 ; \mathrm{df}=133 ; \mathrm{p}=.97)$ and teacher-student interaction $(\mathrm{t}=-1.55 ; \mathrm{df}=131 ; \mathrm{p}=.12)$. Moreover, there were no statistically significant differences between the sixth and eighth graders in overall emotional tone, related to peer relationships $(\chi 2=.243 ; \mathrm{df}=1 ; \mathrm{p}=.622)$ and teacher-pupil interaction $(\chi 2=.999 ; \mathrm{df}=1 ; \mathrm{p}=.318)$.

\section{Discussion}

\subsection{Methodological Reflections}

In this study, mixed methods were employed in order to gain a more in-depth understanding (e.g., Creswell \& Plano Clark, 2007; Johnson et al., 2007) of socially embedded academic emotions. Furthermore, the methods complemented each other. Methodological triangulation was used to improve the validity and credibility of the study (e.g., Patton, 1990).

The Picture task instrument gave us a unique opportunity to collect an extensive data set of pupils' reports of the school environment. The reflective research design made it possible for the pupils to project their perceptions of schools' social learning environments. The research design was based on the assumption that pupils will cast their perceptions, emotions and desires onto neutral pictures (Branthwaite, 2002) that represent normal school day situations. With this research method, we gained new insight concerning this subject matter that is often subconscious and too difficult to articulate. However, it must be noted that this method does not automatically produce descriptions of actual events. Thus, the descriptions are rather projections of pupils' emotions and perceptions of social events of school. However, it may be argued that the results of this study validated the instrument.

Furthermore, we utilized a survey to explore the relationship between pupils' emotions and achievement and school-related wellbeing. The validity and reliability of the survey was satisfactory (Pietarinen et al., 2014). In addition, the internal consistency for the cynicism scale was good. However, it should be noted that further construct validation of the scales is still needed. For example, the scales have not been validated in other countries, school systems, or environments (Pietarinen et al., 2014). Hence, generalizing the results to other school systems and countries should be done with caution because of the distinctive features of Finnish comprehensive school and the limited sample size $(\mathrm{N}=146)$. Despite these limitations, our study provides important insights into pupils' emotions in social interactions in school settings.

\subsection{Theoretical Reflections and Educational Implications}

The main findings of our study showed that the interaction between teachers and peers, especially in informal learning environments, is a central arena for pupils' socially embedded emotions. However, previous emotion literature has neglected social embeddedness of emotions, focusing heavily on exploring academic emotions in formal learning environments, especially concentrating on achievement, engagement and teaching (e.g., Beilock et al., 2010; Frenzel et al., 2009; Hagenauer et al., 2015; Linnenbrink-Garcia et al., 2011; Linnenbrink-Garcia \& Pekrun, 2011; Pekrun et al., 2002). Our results extend the previous research on academic emotions by showing that emotional experiences do not only occur in classrooms and during formal teaching and learning, but also widely in social interactions between classes.

Even though previous literature on recess setting is, as far as we know, very limited, there is prior evidence that pupils' moods when entering class influence emotions experienced during formal learning (Becker et al., 2014). Our study extends this finding, implying that recess is an important part of the pedagogically orchestrated school environment that might have significant impact on learning also during class. Thus, teachers should recognize the significance of pupils' emotions for learning and be able to identify their emotional states. Furthermore, teachers should know how to utilize pupils' positive emotions to support learning as well as identify the situations where the triggers of pupils' negative emotional experiences need to be processed together. For example, pupils' negative emotional experiences during recess might make them incapable of learning, and situations where the teacher keeps pushing further with teaching may lead to mutual frustration and a negative cycle. Hence, it would be important for the teacher to know when existing social problems need to be solved in the beginning of the class, so that the pupils would be more emotionally wired to learn. More research of this is, however, needed. 
Negative emotions embedded in teacher-pupil interaction, both in class and in recess, were related to pupils' misbehavior and teachers' instructional behavior. Accordingly, our study confirms previous findings in the literature (e.g., Becker et al., 2014; Chang, 2013; Gläser-Zikuda \& Fuß, 2008; Rantala \& Määttä, 2012 Sarason, 1984, Ulmanen et al., 2016). Furthermore, described negative emotions were related to lack of social support and help from teachers. Furthermore, our findings showed that emphasizing negative emotions in teacher-pupil interaction was related to cynicism and thriving in school. Pupils who attributed more negative emotions related to teacher-pupil interaction were more cynical and enjoyed going to school less. One reason for this may be that the teacher has an especially significant role in whether the pupils experience going to school as meaningful or not.

Our study suggests that recess settings offer the main arena for social interactions between peers, confirming findings of prior research (Veenstra et al., 2014). For example, positive emotions towards peers were most commonly described in recess settings and were related to having fun with friends. Accordingly, school is a place where pupils get to practice their social skills and build relationships that contribute to their overall development and wellbeing (Bacete et al., 2014; Rubin et al., 2009; Hoferichter et al., 2015). It must, however, be noted that pupils described positive emotions in peer interactions rarely and the explicated emotions were most commonly negative and related to bullying, peer-rejection and misbehavior. Thus, recess is also a setting for negatively loaded social interactions between peers. Previous research has also shown that especially bullying often happens in places without direct teacher supervision such as the recess setting (Veenstra et al., 2014). One reason for the large number of reported negative emotions may be that the negative emotional experiences between peers are seen as highly challenging and burdening experiences, including fear of peer rejection and mockery. Thus, major threats related to peer interactions are commonly pondered. Furthermore, if pupils perceive their own social problem-solving skills as limited, the negative peer interactions might cause even more wonder. Pupils may need more hands-on practice and active ways to process the problems of peer interaction. Hence, active problem-solving guided by teachers might benefit not only the overall emotional climate for learning, but give pupils concrete ways to deal with problems in peer interactions. Surprisingly, attributing negative emotions in peer interaction was not directly connected to cynicism and thriving in school. One reason for this may be that the effect of negative emotions in peer groups are indirect and possibly mediated by more complex factors. More research on negative emotions in peer groups is needed to understand the indirect factors.

Surprisingly, we did not find any differences between sixth and eighth graders' described emotions in teacher-pupil and in peer interactions. Our finding partly contradicts findings of previous studies, suggesting that more positively emotionally toned relationships between teacher and pupils occur in primary school than in secondary school (Hagenauer et al., 2015; Symonds \& Galton, 2014). Furthermore, there are many studies indicating that the emotions experienced, especially in class, are connected to academic achievement (e.g. Beilock et al., 2010; Pekrun et al., 2002). Surprisingly, in this study, pupils described emotional tone in peer and in teacher-pupil interaction did not have a connection with their GPA. One reason for this may be that the impact does not convey to the GPA of all school subjects, but rather the impact may be indirect through school engagement. Previous studies have, for example, shown that pupils' school achievement was associated with their cognitive engagement (Pietarinen et al., 2014).

Finally, this study contributes to the literature of academic emotions on a concept level. Previous studies have prospected academic emotions in schools, but tied them firmly to studying, learning and teaching. Our study however, widens the definition of academic emotions to involve all the pedagogical practices of school, such as recess settings. Furthermore, social embeddedness of emotions have been previously neglected in research in the field of academic emotions. Thus, our study proposes that social embeddedness of academic emotions should be highlighted and focused on in future research.

\section{Acknowledgments}

This work was supported by the Finnish Ministry of Education and Culture and by the grant from Jenny and Antti Wihuri Foundation awarded to Henrika Anttila.

\section{References}

Ainley, M., \& Hidi, S. (2002). Dynamic measures for studying interest and learning. In P. R. Pintrich \& M. L. Maehr (Eds.), New directions in measures and methods. Amsterdam: Elsevier.

Aitor Aritzetaa, A., Balluerkaa, N., Gorostiagaa, A., Alonso-Arbiol, I., Haranburua, M., \& Gartzia, L. (2016). Classroom emotional intelligence and its relationship with school. European Journal of Education and Psychology, 9, 1-8. https://doi.org/10.1016/j.ejeps.2015.11.001 
Anttila, H., Pyhältö, K., Soini, T., \& Pieatarinen, J. (2016). How does it feel to become a teacher? Emotions in teacher education. Social Psychology of Education, 19(3), 451-473. https://doi.org/10.1007/s11218-016-9335-0

Anttila, H., Pyhältö, K., Soini, T., \& Pieatarinen, J. (2017). From anxiety to enthusiasm: emotional patterns among student teachers. European Journal of Teacher Education, 40(4), 447-464. https://doi.org/10.1080/02619768.2017.1349095

Averill, J. R. (1980). A constructivist view of emotions. In R. Plutchik \& H. Kellerman (Eds.), Emotions: Theory research and experience. New York: Academic Press.

Bacete, F., Perrin, G., Schneider, B., \& Blanchard, C. (2014). Effects of school on the well-being of children and adolescents. In A. Ben-Arieh, F. Casas, I. Frønes, \& J. E. Korbin (Eds.), Handbook of child well-Being. Netherlands: Springer.

Barhight, L., Hubbard, J., \& Hyde, C. (2013). Children's Physiological and emotional reactions to witnessing bullying predict bystander intervention. Child Development, 84(1), 375-390. https://doi.org/10.1111/j.1467-8624.2012.01839.x

Barsade, S. G. (2002). The ripple effect: emotional contagion and its influence on group behavior. Administrative Science Quarterly, 47(4), 644-675. https://doi.org/10.2307/3094912

Baudoin, N., \& Galand, B. (2008). Effects of classroom goal structures on student emotions at school. International Journal of Educational Research, 86, 13-22. https://doi.org/ 10.1016/j.ijer.2017.08.010

Baumeister, R. F., \& Bushman, B. J. (2007). Angry emotions and aggressive behaviors. In G. Steffgen \& M. Gollwitzer (Eds.), Emotions and aggressive behaviour. Ashland, OH: Hogrefe \& Huber.

Becker, E. S., Goetz, T., Morger, V., \& Ranellucci, J. (2014). The importance of teachers' emotions and instructional behavior for their students' emotions-An experience sampling analysis. Teaching and Teacher Education, 43, 15-26. https://doi.org/10.1016/j.tate.2014.05.002

Beilock, S., Gunderson, E., Ramirez, G., \& Levine, S. (2010). Female teachers' math anxiety affects girls' math achievement. Proceedings of the National Academy of Science, 107, 1860-1863. https://doi.org/10.1073/pnas.0910967107

Branthwaite, A. (2002). Investigating the power of imagery in marketing communication: Evidence-based techniques. Qulitative Marketing Research: An international Journal, 5(3), 164-171. https://doi.org/10.1108/13522750210432977

Chamberlain, G. P. (2006). Researching strategy formation process: An abductive methodology. Quality and Quantity, 40(2), 289-301. https://doi.org/10.1007/s11135-005-8094-3

Chang M. L. (2013). Toward a theoretical model to understand teacher emotions and teacher burnout in the context of student misbehavior: appraisal, regulation and coping. Motivation \& Emotion, 37, 799-817. https://doi.org/10.1007/s11031-012-9335-0

Creswell, J., \& Plano, C. V. L. (2007). Designing and conducting mixed method research. California: Sage Publications.

Cubukcu, F. (2012). The significance of teachers' academic emotions. Procedia-Social and Behavioral Sciences, 70, 649-653. https://doi.org/10.1016/j.sbspro.2013.01.105

Demetriou, H., Wilson, E., \& Winterbottom, M. (2009). The role of emotion in teaching: are there differences between male and female newly qualified teachers' approaches to teaching? Educational Studies, 35(4), 449-473. https://doi.org/10.1080/03055690902876552

Denham, S., Bassett, H., \& Zinsser, K. (2012). Early childhood teachers as socializers of young children's emotional competence. Early Childhood Education Journal, 40(3), 137-143. https://doi.org/10.1007/s10643-012-0504-2

Do, S., \& Schallert, D. (2004). Emotions and classroom talk: Toward a model of the role of affect in students' experiences of classroom discussions. Journal of Educational Psychology, 96(4), 619-634. https://doi.org/10.1037/0022-0663.96.4.619

Elo, S., \& Kyngäs, H. (2007). The qualitative content analysis process. Journal of Advanced Nursing, 62(1), 107-115. https://doi.org/10.1111/j.1365-2648.2007.04569.x 
Finnish National Agency for Education. (2017). Finnish education in a nutshell [pdf]. Retrieved from http://www.oph.fi/download/171176_finnish_education_in_a_nutshell.pdf

Frenzel, A., Goetz, T., Lüdtke, O., Pekrun, R., \& Sutton, R. (2009). Emotional transmission in the classroom: Exploring the relationship between teacher and student enjoyment. Journal of Educational Psychology, 101, 705-716. https://doi.org/10.1037/a0014695

Frenzel, A., Goetz, T., Pekrun, R., \& Jacob, B. (2009). Antecedents and effects of teachers' emotional experiences: An integrated perspective and empirical test. In P. A. Schutz \& M. Zembylas (Eds.), Advances in teacher emotion research: The impact on teachers' lives. New York: Springer.

Friedlund, A. (1991). Evolution and facial action in reflex, social motive, and paralanguage. Biological Psychology, 32, 3-100. https://doi.org/10.1016/0301-0511(91)90003-Y

Furrer, C., \& Skinner, E. (2003). Sense of relatedness as a factor in children's academic engagement and performance. Journal of Educational Psychology, 95, 148-162. https://doi.org/10.1037/0022-0663.95.1.148

Gläser-Zikuda, M., \& Fuß, M. (2008). Impact of teacher competencies on student emotions: A multi-method approach. International Journal of Educational Research, 47(2), 136-147. https://doi.org/10.1016/j.jijer.2007.11.013

Graham, S., \& Juvonen, J. (1998). Self-blame and peer victimization in middle school: An attributional analysis. Developmental Psychology, 34(3), https://doi.org/10.1037/0012-1649.34.3.587

Grams, S., \& Jurowetzki, R. (2015). Emotions in the Classroom: The Powerful Role of Classroom. In B. Lund \& T. Chami (Eds.), Dealing with Emotions: A Pedagogical Challenge to Innovative. Rotterdam, Holland: Sense Publishers.

Haapala, H., Hirvensalo, M., Laine, K., Laakso, L., Hakonen, H., Lintunen, T., \& Tammelin, T. (2014). Adolescents' physical activity at recess and actions to promote a physically active school day in four Finnish schools. Health Educational Research, 29(5), 840-852. https://doi.org/10.1093/her/cyu030

Hagenauer, G., \& Volet, S. (2014). "I don't think I could, you know, just teach without any emotion": Exploring the nature and origin of university teachers' emotions. Research Papers in Education, 29(2), 240-262. https://doi.org/10.1080/02671522.2012.754929

Hagenauer, G., Hascher, T., \& Volet, S. (2015). Teacher emotions in the classroom: associations with students' engagement, classroom discipline and the interpersonal teacher-student relationship. European Journal of Psychology of Education, 30(4), 385-403. https://doi.org/10.1007/s10212-015-0250-0

Hargreaves, A. (2000). Four ages of professionalism and professional learning. Teachers and Teaching: Theory and Practice, 6(2), 151-182. https://doi.org/10.1080/713698714

Hatfield, E., Cacioppo, J., \& Rapson, R. (1994). Emotional contagion. New York: Cambridge University Press.

Hess, U., \& Kirouac, G. (2004). Emotion expression in Groups. In M. Lewis \& J. M. Haviland-Jones (Eds.), Handbook of Emotions. New York: The Guilford Press

Hoferichter, F., Raufelder, D., \& Eid, M. (2015). Socio-motivational moderators - two sides of the same coin? Testing the potential buffering role of socio-motivational relationships on achievement drive and test anxiety among German and Canadian secondary school students. Frontiers in Psychology, 6, 1675-1688. https://doi.org/10.3389/fpsyg.2015.01675

Ioannidou, F., \& Konstantikak, V. (2008). Empathy and emotional intelligence: What is it really about? International Journal of Caring Sciences, 1(3), 118-123

Johnson, R. B., Onwuebuzie, A. J., \& Turner, L. A. (2007). Toward a definition of mixed methods research. Journal of Mixed Methods Research, 1(2), 112-133. https://doi.org/10.1177/1558689806298224

Juvonen, J., Nishina, A., \& Graham, S. (2000). Peer harassment, psychological adjustment, and school functioning in early adolescence. Journal of Educational Psychology, 92, 349-359. https://doi.org/10.1037/0022-0663.92.2.349

Kemper, T. (1978). A Social interactional theory of Emotions. New York: Wiley.

Klusmann, U., Kunter, M., Trautwein, U., Lüdtke, O., \& Baumert, J. (2008). Teachers' occupational well-being and quality of instruction: The important role of self-regulatory patterns. Journal of Educational Psychology, 100, 702-715. https://doi.org/10.1037/0022-0663.100.3.702 
Kumpulainen, K., \& Lankinen, T. (2012). Striving for Educational Equity and Excellence: Evaluation and Assessment in Finnish Basic Education. In H. Niemi, A. Toom, \& A. Kallioniemi (Eds.), The Principles and Practices of Teaching and Learning in Finnish Schools. Rotterdam: Sense Publishers.

Kunter, M., Klusmann, U., Baumert, J., Richter, D., Voss, T., \& Hachfeld, A. (2013). Professional competence of teachers: effects on instructional quality and student development. Journal of Educational Psychology, 105(3), 805-820. https://doi.org/10.1037/a0032583

Leary, M. (2000). Affect, cognition and the social emotions. In J. Forgas (Eds.), Feeling and thinking. Cambridge, UK: Cambridge University Press.

Lewis, A., Huebner, E., Malone, P., \& Valois, R. (2011). Life Satisfaction and Student Engagement in Adolescents. Journal Youth Adolescence, 40(3), 249-262. https://doi.org/10.1007/s10964-010-9517-6

Linnenbrink-Garcia, L., Rogat, T., \& Koskey, K. (2011). Affect and engagement during small group instruction. Contemporary Educational Psychology, 36(1), 13-24. https://doi.org/10.1016/j.cedpsych.2010.09.001

Lyubomirsky, S., King, L. A., \& Diener, E. (2005). The benefits of frequent positive affect: Does happiness lead to success? Psychological Bulletin, 131(6), 803-855. https://doi.org/10.1037/0033-2909.131.6.803

Madill, R., Gest, S., \& Rodkin, P. (2014). Students' Perceptions of Relatedness in the Classroom: The Roles of Emotionally Supportive Teacher-Child Interactions, Children's Aggressive-Disruptive Behaviors, and Peer Social Preference. School Psychology Review, 43(1), 86-105.

Maria, F., Dos Santos, T., \& Mortimer, E.F. (2010). How emotions shape the relationship between a chemistry teacher and her high school students. International Journal of Science Education, 25(9), 1095-1110. https://doi.org/10.1080/0950069032000052216

Nakahashi, W., \& Ohtsuki, H. (2015). When is emotional contagion adaptive? Journal of Theoretical Biology, 380(7), 480-488. https://doi.org/10.1016/j.jtbi.2015.06.014

Niemi, H. (2012). The Societal Factors Contributing to Education and Schooling in Finland. In H. Niemi, A. Toom, \& A. Kallioniemi (Eds.), The Principles and Practices of Teaching and Learning in Finnish Schools. Rotterdam: Sense Publishers.

Oatley, K. (2000). The sentiments and beliefs of distributed cognition. In N. Frijda, A. Manstead, \& S. Be (Eds.), Emotions and beliefs: How feelings influence thoughts. Cambridge: Cambridge University Press.

Oatley, K., \& Johnson-Laird P. N. (1987). Towards a Cognitive Theory of Emotions. Cognition and Emotion, $1(1), 29-50$.

Parkinson, B., Fischer, A. H., \& Manstead, A. S. R. (2005). Emotion in social relations. New York: Psychology Press.

Patton, M. (1990). Qualitative research and evaluation methods. Newbury Park, CA: Sage Publications.

Pekrun, R. (2006). The control-value theory of achievement emotions: Assumptions, corollaries, and implications for educational research and practice. Educational Psychology Review, 18, 315-341. https://doi.org/10.1007/s10648-006-9029-9

Pekrun, R., \& Linnenbrink-Garcia, L. (2014). Conclusions and future directions. In R. Pekrun \& L. Linnenbrink-Garcia (Eds.), International Handbook of Emotions in Education. New York: Routledge.

Pekrun, R., \& Schutz, P. A. (2007). Where do we go from here? Implications and future directions for inquiry on emotions in education. In P. A. Schutz \& R. Pekrun (Eds.), Emotion in education. San Diego, CA: Academic Press.

Pekrun, R., Goetz, T., Perry, R. P., Kramer, K., \& Hochstadt, M. (2004). Beyond test anxiety: Development and validation of the Test Emotions Questionnaire (TEQ). Anxiety, Stress and Coping, 17, 287-316. https://doi.org/10.1080/10615800412331303847

Pekrun, R., Goetz, T., Titz, W., \& Perry, R. (2002). Academic emotions in students' self-regulated learning and achievement: A program of qualitative and quantitative research. Educational Psychologist, 37(2), 91-105. https://doi.org/10.1207/S15326985EP3702_4

Pekrun, R., Muis, K., Frenzel, A., \& Goetz, T. (2017). Emotions at school. New York: Routledge.

Pietarinen, J., Soini, T., \& Pyhältö, K. (2014). Students' emotional and cognitive engagement as the determinants of well-being and achievement in school. International Journal of Educational Research, 67, 40-51. https://doi.org/10.1016/j.ijer.2014.05.001 
Porr, C., Mayan, M., Graffigna, G., Wall, S., \& Vieira, E. (2001). The evocative power of projective techniques for the elicitation of meaning. International Journal of Qualitative Methods, 10(1), 30-41. https://doi.org/10.1177/160940691101000103

Pyhältö, K., Soini, T., \& Pietarinen, J. (2010). Pupils' pedagogical well-being in comprehensive school - significant positive and negative school experiences of Finnish ninth graders. European Journal of Psychology of Education, 25(2), 207-221. https://doi.org/10.1007/s10212-010-0013-x

Rantala, T., \& Määttä, K. (2012). Ten theses of the joy of learning at primary schools. Early Child Development and Care, 182(1), 87-105. https://doi.org/10.1080/03004430.2010.545124.

Ridgers, N., Stratton, G., \& Fairclough, S. (2006). Physical activity levels of children during school playtime. Sports Medicine, 36(4), 359-371. https://doi.org/10.2165/00007256-200636040-00005

Rimé, B., Finkenauer, C., Luminet, O., Zech, E., \& Philippot, P. (1998). Social sharing of emotion: New evidence and new questions. In W. Stroebe \& M. Hewstone (Eds.), European review of social psychology. Chichester, UK: John Wiley \& Sons.

Rimé, B., Mesquita, B., Philippot, P., \& Boca, S. (1991). Beyond the emotional event: Six studies on the social sharing of emotion. Cognition and Emotion, 5, 435-465. https://doi.org/10.1080/02699939108411052

Rubin, K. H., Bukowski, W. M., \& Laursen, B. (2009). Handbook of peer interactions, relationships and groups. New York/London: The Guilford Press.

Sahlberg, P. (2011). Finnish lessons: What can the world learn from educational change in Finland? New York: Teachers College Press.

Salmela-Aro, K., Kiuru, N., Leskinen, E., \& Nurmi J. (2009). School Burnout Inventory (SBI): Reliability and validity. European Journal of Psychological Assessment, 25, 48-57. https://doi.org/10.1027/1015-5759.25.1.48

Sarason, I. (1984). Stress, Anxiety, and cognitive interference: Reactions to tests. Journal of Personality and Social Psychology, 46, 929-938. https://doi.org/10.1037/0022-3514.46.4.929

Schutz, P., Hong, J., Cross, D., \& Osbon, J. (2006). Reflections on Investigating Emotions in Educational Activity Settings. Educational Psychology Review, 18, 343-360. https://doi.org/10.1007/s10648-006-9030-3

Singer, T., \& Lamm, C. (2009). The Social Neuroscience of Empathy. Annals of the New York Academy of Sciences, 1156, 81-96. https://doi.org/10.1111/j.1749-6632.2009.04418

Soini, T., Pyhältö, K., \& Pietarinen, J. (2010). Pedagogical well-being-Reflecting learning and well-being in teachers' work. Teaching and Teachers: Theory and Practice, 16, 735-751. https://doi.org/10.1080/13540602.2010.517690

Steinberg, L., \& Morris, A. S. (2001). Adolescent development. Annual Review of Psychology, 52, 83-110. https://doi.org/10.1146/annurev.psych.52.1.83

Sutton, R. E., \& Wheatley, K. F. (2003). Teachers' emotions and teaching: A review of the literature and directions for future research. Educational Psychology Review, 15(4), 327-358. https://doi.org/10.1023/A:1026131715856

Symonds, J., \& Galton, M. (2014). Moving to the next school at age 10-14 years: an international review of psychological development at school transition. Review of Education, 2(1), 1-27. https://doi.org/10.1002/rev3.3021

Tamir, M. (2009). What Do people Want to Feel and Why? Pleasure and Utility in Emotion Regulation. $A$ Journal Association for Psychological Science, 18(2), 101-105. https://doi.org/10.1111/j.1467-8721.2009.01617.x

Ulmanen, S., Soini, T., Pietarinen, J., \& Pyhalto, K. (2016). Students' experiences of the development of emotional engagement julkaisussa. International Journal of Educational Research, 79, 86-96. https://doi.org/10.1016/j.jijer.2016.06.003

Veenstra, R., Lindenberg, S., Huitsing, G., Sainio, M., \& Salmivalli, C. (2014). The role of teachers in bullying: The relation between antibullying attitudes, efficacy, and efforts to reduce bullying. Journal of Educational Psychology, 106, 1135-1143. https://doi.org/10.1037/a0036110 
Véronneau, M. H., \& Vitaro, F. (2007). Social experience with peers and high school graduation: A review of theoretical and empirical research. Educational Psychology, 27, 419-445. https://doi.org/10.1080/01443410601104320

Volet, S., \& Järvelä, S. (Eds.). (2001). Motivation in learning contexts. London: Pergamon.

Wentzel, K. R., \& Caldwell, K. (1997). Friendships, peer acceptance, and group membership: Relations to academic achievement in middle school. Child Development, 68, 1198-1209. https://doi.org/10.2307/1132301

Witkow, M. R., \& Fuligni, A. J. (2010). In-school versus out-of-school friendships and academic achievement among an ethnically diverse sample of adolescents. Journal of Research on Adolescence, 20, 630-651. https://doi.org/https://doi.org/10.1111/josi.12120

\section{Copyrights}

Copyright for this article is retained by the author(s), with first publication rights granted to the journal.

This is an open-access article distributed under the terms and conditions of the Creative Commons Attribution license (http://creativecommons.org/licenses/by/4.0/). 